\author{
M.K. Kudaibergenov ${ }^{1}$, A.L. Karchevsky ${ }^{2,3}$, K.T. Iskakov ${ }^{4}$ \\ ${ }^{1}$ Kazakh Humanitarian and Law Innovative University, Semey, Kazakhstan; \\ ${ }^{2}$ Sobolev Institute of Mathematics, Novosibirsk, Russia; \\ ${ }^{3}$ Novosibirsk State University, Russia; \\ ${ }^{4}$ L.N. Gumilyov Eurasian National University, Astana, Kazakhstan \\ (E-mail: melskk@mail.ru)
}

\title{
Stress-strain state horizontal coal seam of finite length
}

\begin{abstract}
As the result of work, analytical expressions for calculation of tension in coal stratum of terminating length, which is under the influence of overlying breeds and is between two drifts are received. The decision is presented in the form of the sum of a polynom and a convergent series. For determination of coefficients of a row it is not required to solve the infinite systems of the algebraic equations. It promotes fast numerical finding of the required sizes with an accuracy, sufficient for practice. The given decision can be used for interpretation of data of geomechanical monitoring at combinegouge of coal in the conditions of real time and for monitoring of tension in the developed coal layer for the purpose of prediction of a possibility of mountain emission that still is very relevant problem of safety of mining operations.
\end{abstract}

Keywords: stress, plane problem of the theory of elasticity, biharmonic equation, coal bed, model of coal layer.

\section{Introduction}

The paper deals with the plane problem of the deformation of a horizontal coal bed of finite length that is under the influence of overlying rocks and lies between two drifts. An analytical solution in the form of a series is constructed. It takes a small amount of time to calculate it. To calculate ita small amount of time is needed. The method is specifically designed for monitoring of geomechanical fields during the development of coal seams in real time.

Conveyor technologies for coal extraction are increasingly used for underground mining. In this connection, the security problems associated with the increase in the likelihood of occurrence of mountain impacts and sudden gas releases are exacerbated [1]. In mines and mining camps the passivesystemsof monitoring of environment are used. They record microseismic emission (ITU), which occurs due to deformation of the rock mass caused by a quasistatic change in stresses during cleaning operations $[2,3]$. Interpretation of the received data on the spot is carried out locally by statistical methods $[4,5]$. On the other hand, there are significant correlations between the characteristics of the ITU and the integral parameters of the stress-strain state of rocks [6]. However, their use in practice is difficult, because the currently available numerical methods for calculating stress and strain fields in geo-environments [7-9] and, in particular, of carbonaceous massifs [10], despite the universality and existence of many commercial codes (ANSYS, ABACUS, FLAC, etc.), it is very difficult to use for the rapid estimation of geomechanical fields with the purpose of making decisions over times of the order of tens of seconds, which is required when forecasting technogenic dynamic events [2]. Therefore, the development of analytical methods for calculating geomechanical fields remains relevant. These methods allow obtaining the required solution for the minimum time required in practice.

The mathematically stated problem reduces to solving a two-dimensional homogeneous biharmonic equation. Numerous methods have been proposed to solve it. It is necessary to mention solutions in the form of polynomials, solutions of Fileon and Ribier. However, these solutions are not suitable for any kind of boundary conditions. There is an approach of the so-called nonclosed solution, when the solution is represented as the sums of several series, when the coefficient of one series is expressed in terms of all the coefficients of the second series, i.e. an infinite system of linear algebraic equations is obtained for finding coefficients. If it is possible to prove its completely regularity, then it is possible to use the simple reduction method. However, this approach is associated with a great deal of computation. It is possible to find a solution with the help of fundamental beam functions A.N. Krylov, but among them there are hyperbolic sines and cosines, which can lead to large errors during computationin large domains. To solve the biharmonic equation, there are other approaches (see, for example, [11-14]), which compare solutions obtained by various methods (they can be found in the work) [15]. 
In our opinion, the most promising approach seems to be S.A. Khalilov's approach. They were offered and studied special basis functions [16, 17], which allow, first, to obtain a solution in the form of a series; secondly, simple actions are performed to search for the coefficients of this series; it is not necessary to solve infinite systems of linear algebraic equations. This approach was proposed to solve the applied problems of aircraft building (see, for example [15-24]). It was shown that the numerical solution of the biharmonic equation, constructed with the help of proposed functions, is calculated very accurately. The maximum deviation is localized near the corner points of the domain (see, for example, [15-20], etc.) and is small (about 1.2\%), the largest error is achieved for a square area, the more the rectangular domain differs from the square, the less the calculation error.

We used the experience of S.A. Khalilov and his disciples for the construction of an algorithm for the rapid calculation of stresses in a coal-rock massif. This algorithm will be used in the future to interpret geological information in order to predict the possibility of mining, which is still a very urgent task of ensuring the safety of mining operations. The first attempts in this direction were made in [25, 26].

\section{Formulation of the task}

It is necessary to calculate stress fields in a coal seam of finite length lying between two drifts. Due to the long length of the reservoir compared to its thickness and distance between the drifts, we assume that the model of a flat deformed state is applicable [27]. In this case, the Navier equilibrium equation is written in the following form:

$$
\frac{\partial \sigma_{x}}{\partial x}+\frac{\partial \tau_{x z}}{\partial z}=0, \quad \frac{\partial \tau_{x z}}{\partial x}+\frac{\partial \sigma_{z}}{\partial z}=0
$$

The stress state in the reservoir is described by the equation of continuity of deformation of Saint-Venant

$$
\frac{\partial^{2} \varepsilon_{x}}{\partial z^{2}}+\frac{\partial^{2} \varepsilon_{z}}{\partial x^{2}}=\frac{\partial^{2} \gamma_{x z}}{\partial x \partial z}
$$

and Hooke's law

$$
\varepsilon_{x}=\frac{1}{E^{\prime}}\left(\sigma_{x}-\nu^{\prime} \sigma_{z}\right), \quad \varepsilon_{z}=\frac{1}{E^{\prime}}\left(\sigma_{z}-\nu^{\prime} \sigma_{x}\right), \quad \gamma_{x z}=\frac{2\left(1+\nu^{\prime}\right)}{E^{\prime}} \tau_{x z} .
$$

Here $E^{\prime}$ and $\nu^{\prime}$ are the Young's modulus and the Paussson coefficient for the plane problem of the deformed state [27].

We assume that the boundary conditions hold

$$
\left.\sigma_{z}\right|_{z= \pm l_{z}}=\left\{\begin{array}{c}
f_{1}(x) \\
f_{2}(x)
\end{array} ;\left.\quad \tau_{x z}\right|_{z= \pm l_{z}}=\left\{\begin{array}{c}
g_{1}(x) \\
g_{2}(x)
\end{array}\right.\right.
$$

and the matching conditions at the corner points: $g_{j}\left( \pm l_{x}\right)=0(j=1,2)$.

In the simple case, we can assume: $f_{1}(x)=f_{2}(x), g_{1}(x)=-g_{2}(x)$.
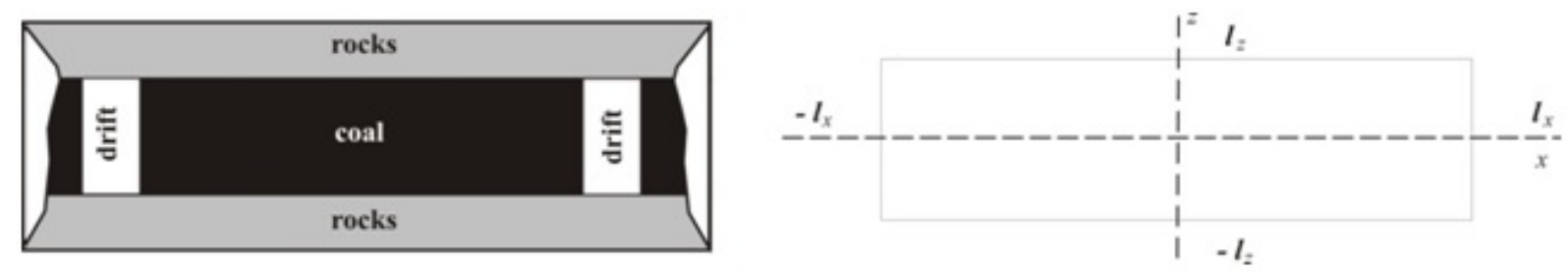

Figure. Coal layer model and coordinate system adopted in the paper

We consider that the considered system is balanced (the coal seam, being under the influence of forces on it, is stationary) (see. Fig.). In this case, the moment of forces and the sum of the forces acting on the layer must be zero. That is, the following equations must be satisfied:

$$
\int_{-l_{x}}^{l_{x}}\left[x \sigma_{z}\left(x, l_{z}\right)-l_{z} \tau_{x z}\left(x, l_{z}\right)\right] d x+\int_{l_{x}}^{-l_{x}}\left[x \sigma_{z}\left(x,-l_{z}\right)+l_{z} \tau_{x z}\left(x,-l_{z}\right)\right] d x=0
$$




$$
\int_{-l_{x}}^{l_{x}} \sigma_{z}\left(x, l_{z}\right) d x=\int_{-l_{x}}^{l_{x}} \sigma_{z}\left(x,-l_{z}\right) d x, \quad \int_{-l_{x}}^{l_{x}} \tau_{x z}\left(x, l_{z}\right) d x=\int_{-l_{x}}^{l_{x}} \tau_{x z}\left(x,-l_{z}\right) d x
$$

or, taking into account (4),

$$
\begin{aligned}
& \frac{1}{2}\left(\int_{-l_{x}}^{l_{x}} x f_{1}(x) d x-\int_{-l_{x}}^{l_{x}} x f_{2}(x) d x\right)=l_{z} \int_{-l_{x}}^{l_{x}} g_{1}(x) d x \\
& \int_{-l_{x}}^{l_{x}} f_{1}(x) d x=\int_{-l_{x}}^{l_{x}} f_{2}(x) d x, \quad \int_{-l_{x}}^{l_{x}} g_{1}(x) d x=\int_{-l_{x}}^{l_{x}} g_{2}(x) d x .
\end{aligned}
$$

Following the well-known approach for calculating stresses (see, for example, [27]), we introduce the Erie function and obtain the differential equation to which it satisfies.

A consequence of relations (2)-(3) is the equation

$$
\frac{\partial^{2}}{\partial z^{2}}\left(\sigma_{x}-\nu^{\prime} \sigma_{z}\right)+\frac{\partial^{2}}{\partial x^{2}}\left(\sigma_{z}-\nu^{\prime} \sigma_{x}\right)=2\left(1+\nu^{\prime}\right) \frac{\partial^{2}}{\partial x \partial z} \tau_{x z}
$$

It follows from (1)-(3), (7) that

$$
\Delta\left(\sigma_{x}+\sigma_{z}\right)=0
$$

We introduce the Erie function $\varphi$ so that equations (1) are satisfied automatically

$$
\sigma_{x}=\frac{\partial^{2} \varphi}{\partial z^{2}}, \quad \sigma_{z}=\frac{\partial^{2} \varphi}{\partial x^{2}}, \quad \tau_{x z}=-\frac{\partial^{2} \varphi}{\partial x \partial z},
$$

then from (8) for the Erie $\varphi$ function the biharmonic equation will take place:

$$
\Delta^{2} \varphi=0 .
$$

To solve equation (10), from (4) and (9) follow the boundary conditions:

$$
\begin{aligned}
& \left.\varphi_{x x}\right|_{z= \pm l_{z}}=\left\{\begin{array}{l}
f_{1}(x) \\
f_{2}(x)
\end{array},\left.\quad \varphi_{x z}\right|_{z= \pm l_{z}}=\left\{\begin{array}{l}
g_{1}(x) \\
g_{2}(x)
\end{array},\right.\right. \\
& \left.\varphi_{z z}\right|_{x= \pm l_{x}}=0,\left.\quad \varphi_{x z}\right|_{x= \pm l_{x}}=0 .
\end{aligned}
$$

Thus, in order to find the stresses $\sigma_{x}, \sigma_{z}$, and $\tau_{x z}$ in the domain $\left[-l_{x}, l_{x}\right] \times\left[-l_{z}, l_{z}\right]$ it is necessary to find the solution of the problem (10)-(11), and then use the representations (9).

To apply the mathematical technique (as in the case of using the solutions of Fileon or Ribiere), it is necessary that for the basis functions $H_{m}(x)$ on the interval $\left[-l_{x}, l_{x}\right]$ the following conditions exist at the ends: $H_{m}\left( \pm l_{x}\right)=0, H_{m}^{\prime}\left( \pm l_{x}\right)=0$. The functions $\sin \left(\pi x / l_{x}\right)$ or $\cos \left(\pi x / l_{x}\right)$ do not satisfy such conditions.

\section{Selection of basic functions}

S.A. Khalilov proposed to use the basis functions $H_{m}(x)[16,17]$ for the solution of the biharmonic equation of the following form:

$$
H_{m}(x)=P_{m+4}^{4}(x), \quad m=0,1,2, \ldots,
$$

where $P_{m+4}^{4}(x)$ are normalized adjoint Legendre polynomials. The system of functions $\left\{H_{m}(x)\right\}_{m=0}^{\infty}$ is complete and orthonormal on the interval $[-1,1]$.

A continuous function $s(x)$ with boundary values $s( \pm 1)=0, s^{\prime}( \pm 1)=0$ can be decomposed into the Fourier series in the system of functions $\left\{H_{m}(x)\right\}_{n=0}^{\infty}$, the series converges absolutely and uniformly.

The presentation takes place $[16,17]$

$$
H_{m}(x)=\left(1-x^{2}\right)^{2} \sum_{k=0}^{[m / 2]} W_{m k} x^{m-2 k}, \quad W_{m k}=\frac{(-1)^{k}}{2^{m+3}} \sqrt{\frac{m !(2 m+9)}{2(m+8) !}} \frac{(2 m-2 k+7) !}{(m-k+3) ! k !(m-2 k) !},
$$


$([\cdot]$ is the integer part of a number), the recurrence formula

$$
\begin{gathered}
H_{m}(x)=\xi_{m} x H_{m-1}(x)-\zeta_{m} H_{m-2}(x), \quad m=1,2, \ldots, \quad H_{-1}(x)=0, \quad H_{0}(x)=W_{00}\left(1-x^{2}\right)^{2}, \\
\xi_{m}=\sqrt{\frac{(2 m+9)(2 m+7)}{m(m+8)}}, \quad \zeta_{m}=\sqrt{\frac{(m-1)(m+7)(2 m+9)}{m(m+8)(2 m+5)}}
\end{gathered}
$$

and the following equalities $[17,18]$ :

$$
\begin{gathered}
\left\|H_{n}^{\prime}\right\|_{[-1,1]}^{2}=\frac{1}{15}(2 n+9)\left(n^{2}+9 n+5\right) ; \\
\left\|H_{n}^{\prime \prime}\right\|_{[-1,1]}^{2}=\frac{1}{4}(2 n+9)\left((n+2)(n+7)\left[1+\frac{1}{60} n(n+2)(n+7)(n+9)\right]-\right. \\
\left.-n(n+9)\left[3+\frac{1}{84}(n-1)(n+4)(n+5)(n+10)\right]\right) .
\end{gathered}
$$

S.A. Khalilov and his co-authors have been shown and shown on numerical examples [15-20] that the functions $H_{m}^{\prime}(x)$ and $H_{m}^{\prime \prime}(x)$ are quasi-orthogonal in the sense of the following conditions:

$$
\frac{\left\langle H_{n}^{(k)}(x), H_{m}^{(k)}(x)\right\rangle}{\left\|H_{n}^{(k)}(x)\right\|\left\|H_{m}^{(k)}(x)\right\|}=\theta, \quad|\theta| \approx 0, \quad m \neq n, \quad k=1,2,
$$

This remarkable property of these functions made it possible to apply the Bubnov-Galerkin procedure to the search for the solution of the biharmonic equation and greatly simplify it.

In this paper, the functions $X_{m}(x ; L)=(1 / \sqrt{L}) H_{m}(x / L)$ will be used. These functions are orthonormal on the interval $[-L, L]$. For their derivatives, the equalities

$$
\left\|X_{m}^{\prime}\right\|_{[-L, L]}^{2}=L^{-2}\left\|H_{m}^{\prime}\right\|_{[-1,1]}^{2}, \quad\left\|X_{m}^{\prime \prime}\right\|_{[-L, L]}^{2}=L^{-4}\left\|H_{m}^{\prime \prime}\right\|_{[-1,1]}^{2} .
$$

Below we need expansions of functions in a series in the derivatives of the functions $X_{m}(x, L)$. form

The expansion of the continuous function $s(x)(s( \pm L)=0)$ in a series in the functions $X_{m}^{\prime}(x ; L)$ has the

$$
s(x)=\frac{3}{4 L} \int_{-L}^{L} s(y) d y \cdot\left(1-\frac{x^{2}}{L^{2}}\right)+\sum_{n=0}^{\infty} c_{m}^{S} X_{m}^{\prime}(x ; L) .
$$

The expansion of the continuous function $s(x)(|s(x)|<\infty)$ in a series in the functions $H_{k}^{\prime \prime}(x ; L)$ has the form

$$
s(x)=-\frac{3}{2 L^{3}} \int_{-L}^{L} y s(y) d y \cdot x+\frac{1}{4 L} \int_{-L}^{L} s(y) d y+\sum_{m=0}^{\infty} c_{m}^{\Phi} X_{m}^{\prime \prime}(x ; L) .
$$

The decomposition data were obtained in [28].

\section{Construction of the solution of the biharmonic equation}

First of all, we introduce some notation. Let the functions $f_{j}(x)$ и $g_{j}(x)(j=1,2)$ be representable in the form of series

$$
\begin{aligned}
& f_{j}(x)=f_{-2}^{j} \cdot x+f_{-1}^{j}+\sum_{m=0}^{\infty} f_{m}^{j} X_{m}^{\prime \prime}\left(x ; l_{x}\right), \quad f_{-1}^{j}=\frac{1}{4 l_{x}} \int_{-l_{x}}^{l_{x}} f_{j}(s) d s, \quad f_{-2}^{j}=-\frac{3}{2 l_{x}^{3}} \int_{-l_{x}}^{l_{x}} s f_{j}(s) d s \\
& g_{j}(x)=g_{-1}^{j}\left(1-\frac{x^{2}}{l_{x}^{2}}\right)+\sum_{m=0}^{\infty} g_{m}^{j} X_{m}^{\prime}\left(x ; l_{x}\right), \quad g_{-1}^{j}=\frac{3}{4 l_{x}} \int_{-l_{x}}^{l_{x}} g_{j}(s) d s .
\end{aligned}
$$


From conditions (6) it follows that:

$$
f_{-1}^{1}=f_{-1}^{2} \equiv F, \quad g_{-1}^{1}=g_{-1}^{2}=G, \quad \frac{1}{2}\left(f_{-2}^{1}-f_{-2}^{2}\right)=-\frac{2 l_{z}}{l_{x}^{2}} G .
$$

We denote by

$$
\frac{1}{2}\left(f_{-2}^{1}+f_{-2}^{2}\right)=H
$$

We seek the solution of the biharmonic equation in the form

$$
\varphi(x, z)=\varphi_{1}(x, z)+\varphi_{2}(x, z) .
$$

The function $\varphi_{1}(x, z)$ is a solution of the biharmonic equation (10) and satisfies the boundary conditions

$$
\begin{gathered}
\left.\frac{\partial^{2} \varphi_{1}}{\partial x^{2}}\right|_{z= \pm l_{z}}=\left\{\begin{array}{l}
f_{-2}^{1} \\
f_{-2}^{2}
\end{array}\right\} \cdot x+F,\left.\quad \frac{\partial^{2} \varphi_{1}}{\partial x \partial z}\right|_{z= \pm l_{z}}=-G\left(1-\frac{x^{2}}{l_{x}^{2}}\right) ; \\
\left.\frac{\partial^{2} \varphi_{1}}{\partial z^{2}}\right|_{z= \pm l_{x}}=0,\left.\quad \frac{\partial^{2} \varphi_{1}}{\partial x \partial z}\right|_{z= \pm l_{z}}=0 .
\end{gathered}
$$

Using the method of undetermined coefficients, it is not difficult to obtain $\varphi_{1}(x, z)$ as a polynomial:

$$
\varphi_{1}(x, z)=\frac{H}{6} x^{3}+\frac{F}{2} x^{2}-\frac{G}{3 l_{x}^{2}} x^{3} z+G x z .
$$

Obviously, the function $\varphi_{1}(x, z)$ is found up to linear functions of $x$ and $z$, since the above-mentioned boundary conditions do not ensure the uniqueness of the solution of the biharmonic equation.

The function $\varphi_{2}(x, z)$ is a solution of the biharmonic equation (10) and satisfies the boundary conditions

$$
\begin{gathered}
\left.\frac{\partial^{2} \varphi_{2}}{\partial x^{2}}\right|_{z= \pm l_{z}}=\sum_{m=0}^{\infty}\left\{\begin{array}{l}
f_{m}^{1} \\
f_{m}^{2}
\end{array}\right\} X_{m}^{\prime \prime}\left(x ; l_{x}\right),\left.\quad \frac{\partial^{2} \varphi_{2}}{\partial x \partial z}\right|_{z= \pm l_{z}}=-\sum_{m=0}^{\infty}\left\{\begin{array}{l}
g_{m}^{1} \\
g_{m}^{2}
\end{array}\right\} X_{m}^{\prime}\left(x ; l_{x}\right) ; \\
\left.\frac{\partial^{2} \varphi_{2}}{\partial z^{2}}\right|_{x= \pm l_{x}}=0,\left.\quad \frac{\partial^{2} \varphi_{2}}{\partial x \partial z}\right|_{x= \pm l_{x}}=0 .
\end{gathered}
$$

These boundary conditions automatically satisfy the relations (6) by the properties of the functions $X_{m}\left(x ; l_{x}\right)$ $(\forall m)$.

An approximate analytic solution $\varphi_{2}(x, z)$ will be sought in the form

$$
\varphi_{2}(x, z)=\sum_{m=0}^{\infty} R_{m}(z) X_{m}\left(x ; l_{x}\right)
$$

The Bubnov-Galerkin procedure applied to the solution of the homogeneous biharmonic equation (10) leads to an infinite system of ordinary differential equations

$$
\sum_{m=0}^{\infty}\left[R_{m}\left\langle X_{m}^{\prime \prime}, X_{s}^{\prime \prime}\right\rangle-2 R_{m}^{\prime \prime}\left\langle X_{m}^{\prime}, X_{s}^{\prime}\right\rangle+R_{m}^{\prime \prime \prime \prime} \delta_{m s}\right]=0, \quad s=0,1,2 \ldots
$$

here $\delta_{m s}$ - is the Kronecker symbol.

We use the property of quasiorthogonality of the first and second derivatives of the functions $X_{m}\left(x ; l_{x}\right)$, from (12) we obtain the problems

$$
R_{m}^{\prime \prime \prime \prime}-2 c_{m}^{2} R_{m}^{\prime \prime}+d_{m}^{4} R_{m}=0, \quad R_{m}\left( \pm l_{x}\right)=\left\{\begin{array}{l}
f_{m}^{1} \\
f_{m}^{2}
\end{array}, \quad R_{m}^{\prime}\left( \pm l_{x}\right)=\left\{\begin{array}{l}
g_{m}^{1} \\
g_{m}^{2}
\end{array}, \quad m=0,1,2, \ldots\right.\right.
$$

where $c_{m}^{2}=\left\|X_{m}^{\prime}\left(\cdot ; l_{x}\right)\right\|^{2}$ and $d_{m}^{4}=\left\|X_{m}^{\prime \prime}\left(\cdot ; l_{x}\right)\right\|^{2}$. 
Since $d_{m}>c_{m}$ for all $m$ [17], the four roots of the characteristic equation can be found in the form: $\pm b_{m} \mathrm{e}^{ \pm i \vartheta_{m}}$, where $2 \vartheta_{m}=\operatorname{arctg} \sqrt{d_{m}^{4} / c_{m}^{4}-1}$. Consequently, the solutions of problems (13) have the form

$$
\begin{gathered}
R_{m}(z)=\hat{L}_{m} \sin \left(\vartheta_{m} z\right) \operatorname{sh}\left(d_{m} z\right)+\hat{K}_{m} \cos \left(\vartheta_{m} z\right) \operatorname{ch}\left(d_{m} z\right)+ \\
+\tilde{L}_{m} \sin \left(\vartheta_{m} z\right) \operatorname{ch}\left(d_{m} z\right)+\tilde{K}_{m} \cos \left(\vartheta_{m} z\right) \operatorname{sh}\left(d_{m} z\right) ; \\
\hat{L}_{m}=\frac{\vartheta_{m} \sin \left(\vartheta_{m} l_{z}\right) \operatorname{ch}\left(d_{m} l_{z}\right)-d_{m} \cos \left(\vartheta_{m} l_{z}\right) \operatorname{sh}\left(d_{m} l_{z}\right)}{\Delta_{1}}\left(f_{m}^{1}+f_{m}^{2}\right)-\frac{\cos \left(\vartheta_{m} l_{z}\right) \operatorname{ch}\left(d_{m} l_{z}\right)}{\Delta_{1}}\left(g_{m}^{1}-g_{m}^{2}\right) ; \\
\hat{K}_{m}=\frac{\vartheta_{m} \cos \left(\vartheta_{m} l_{z}\right) \operatorname{sh}\left(d_{m} l_{z}\right)+d_{m} \sin \left(\vartheta_{m} l_{z}\right) \operatorname{ch}\left(d_{m} l_{z}\right)}{\Delta_{1}}\left(f_{m}^{1}+f_{m}^{2}\right)+\frac{\sin \left(\vartheta_{m} l_{z}\right) \operatorname{sh}\left(d_{m} l_{z}\right)}{\Delta_{1}}\left(g_{m}^{1}-g_{m}^{2}\right) ; \\
\tilde{L}_{m}=\frac{\vartheta_{m} \sin \left(\vartheta_{m} l_{z}\right) \operatorname{sh}\left(d_{m} l_{z}\right)-d_{m} \cos \left(\vartheta_{m} l_{z}\right) \operatorname{ch}\left(d_{m} l_{z}\right)}{\Delta_{2}}\left(f_{m}^{1}-f_{m}^{2}\right)-\frac{\cos \left(\vartheta_{m} l_{z}\right) \operatorname{sh}\left(d_{m} l_{z}\right)}{\Delta_{2}}\left(g_{m}^{1}+g_{m}^{2}\right) ; \\
\tilde{K}_{m}=\frac{\vartheta_{m} \cos \left(\vartheta_{m} l_{z}\right) \operatorname{ch}\left(d_{m} l_{z}\right)+d_{m} \sin \left(\vartheta_{m} l_{z}\right) \operatorname{sh}\left(d_{m} l_{z}\right)}{\Delta_{2}}\left(f_{m}^{1}-f_{m}^{2}\right)+\frac{\sin \left(\vartheta_{m} l_{z}\right) \operatorname{ch}\left(d_{m} l_{z}\right)}{\Delta_{2}}\left(g_{m}^{1}+g_{m}^{2}\right) ; \\
\Delta_{1}=\vartheta_{m} \operatorname{sh}\left(2 d_{m} l_{z}\right)+d_{m} \sin \left(2 \vartheta_{m} l_{z}\right), \quad \Delta_{2}=\vartheta_{m} \operatorname{sh}\left(2 d_{m} l_{z}\right)-d_{m} \sin \left(2 \vartheta_{m} l_{z}\right) .
\end{gathered}
$$

5 The resulting expressions for stresses

Summarizing the above expressions, we arrive at the expression

$$
\varphi(x, z)=\frac{H}{6} x^{3}+\frac{F}{2} x^{2}-\frac{G}{3 l_{x}^{2}} x^{3} z+G x z+\sum_{m=0}^{\infty} R_{m}(z) X_{m}\left(x ; l_{x}\right),
$$

where all the necessary quantities are obtained above. From the definition (9) for the stresses, we obtain the following equalities:

$$
\begin{gathered}
\sigma_{x}(x, z)=\sum_{m=0}^{\infty} R_{m}^{\prime \prime}(z) X_{m}\left(x ; l_{x}\right) ; \\
\sigma_{z}(x, z)=H x+F-2 \frac{G}{l_{x}^{2}} x z+\sum_{m=0}^{\infty} R_{m}(z) X_{m}^{\prime \prime}\left(x ; l_{x}\right) ; \\
\tau_{x z}(x, z)=-G\left(1-\frac{x^{2}}{l_{x}^{2}}\right)-\sum_{m=0}^{\infty} R_{m}^{\prime}(z) X_{m}^{\prime}\left(x ; l_{x}\right) .
\end{gathered}
$$

\section{Conclusion}

Analytic expressions are constructed for the approximate calculation of stresses in a coal seam of finite length that are under the influence of overlying rocks and lie between two drifts. For acceptable accuracy, 20-40 series members are required for the expansion of the functions $f_{j}$ and $g_{j}$, so the stress distribution used to interpret the geomechanical monitoring data for the combine harvesting of stocks can be determined in real time.

\section{References}

1 Пучков Л.А. Извлечение метана из угольных пластов / Л.А. Пучков, С.В. Сластунов, К.С. Коликов. - М.: Изд-во Моск. гос. горного ун-та, 2002. - 384 с.

2 Захаров В.И., Сейсмоакустическое прогнозирование и контроль состояния и свойств горных пород при разработке угольных месторождений. - М.: ИГД им. А.А. Скочинского, 2002. - 172 с.

3 Zhenbi L. Microseism Monitoring System for Coal and Gas Outburst / L.Zhenbi, Zh.Baiting // International Journal of Computer Science Issues. - 2012. - Vol. 9. - Issue 5. - No. 1. - P. 24-28.

4 Журков С.Н. К вопросу о физической основе прочности / С.Н. Журков // Физика твердого тела 1985. - T. 22. - № 11. - С. 3344-3349. 
5 Li T.B. Comprehensive integrated methods of rockburst prediction in underground engineering / T.B. Li, X.P. Xiao // Advance in Earth Science. - 2008. - Vol. 23. - No. 5. - P. 533-540.

6 Назаров Л.А. Эволюция геомеханических полей и техногенная сейсмичность при отработке месторождений полезных ископаемых / Л.А. Назаров, Л.А. Назарова, А.Ф. Ярославцев, И.А. Мирошниченко, Е.В. Васильева // Физико-технические проблемы разработки полезных ископаемых. - 2011. - № 6. - C. 6-13.

7 Амусин Б.З. Метод конечных элементов при решении задач горной геомеханики / Б.З. Амусин, А.Б. Фадеев. - М.: Недра, 1975. - 144 с.

8 Zienkiewicz O.C. The Finite Element Method for Solid and Structural Mechanics / O.C. Zienkiewicz, R.L. Taylor. - Elsevier, 2005. - 631 p.

9 Дядьков П.Г. Численное моделирование напряженного состояния земной коры и условий возникновения динамической неустойчивости сейсмоактивных разломов при рифтогенезе / П.Г. Дядьков, Л.А. Назаров, Л.А. Назарова // Геология и геофизика. - 1997. - Т. 38. - № 12. - С. 2001-2010.

10 Назарова Л.А. Реконструкция объемных полей напряжений в углепородном массиве на основе решения обратной задачи по томографическим данным / Л.А. Назарова, Л.А. Назаров, М.И. Протасов // Физико-технические проблемы разработки полезных ископаемых. - 2016. - № 4. - С. $12-21$.

11 Александров А.В. Основы теории упругости и пластичности / А.В. Александров, В.Д. Потапов. М.: Высш. шк., 1990. - 400 с.

12 Безухов Н.И. Основы теории упругости, пластичности и ползучести / Н.И. Безухов. - М.: Высш. шк., 1968. - 512 с.

13 Киселев В.А. Плоская задача теории упругости / В.А. Киселев. - М.: Высш. шк., 1976. - 151 с.

14 Самуль В.И. Основы теории упругости и пластичности / В.И. Самуль. - М.: Высш. шк., 1982. $264 \mathrm{c}$.

15 Халилов С.А. Построение и исследование аналитико-численного решения задачи об изгибе жёстко защемлённой прямоугольной пластины / С.А. Халилов, В.Б. Минтюк, Д.А. Ткаченко // Открытые информационные и компьютерные интегрированные технологии. - 2011. - № 49. - С. 81-94.

16 Халилов С.А. Об одной системе координатных функций для решения краевых задач теории пластин и оболочек / С.А. Халилов // Прочность конструкций летательных аппаратов: темат. сб. науч. тр. - Харьков: ХАИ, 1977. - Вып. 4. - С. 60-65.

17 Халилов С.А. Новые системы ортонормированных многочленов, некоторые их свойства и приложения / С.А. Халилов // Прочность конструкций летательных аппаратов: темат. сб. науч. тр. Харьков: ХАИ, 1978. - Вып. 5. - С. 46-56.

18 Халилов С.А. Вычисление некоторых определённых интегралов, содержащих присоединённые функции Лежандра второго и четвёртого порядков / С.А. Халилов // Прочности конструкций летательных аппаратов: темат. сб. науч. тр. - Харьков: ХАИ, 1984. - Вып. 7. - С. 158-165.

19 Халилов С.А. Построение и исследование приближённого аналитического решения бигармонической проблемы в прямоугольнике при однородных главных краевых условиях / С.А. Халилов, В.Б. Минтюк, Д.А. Ткаченко // Авиационно-космическая техника и технология. - 2013. - № 2. - С. 40-49.

20 Халилов С.А. Приближенное аналитическое решение бигармонической проблемы в прямоугольнике при однородных главных краевых условиях на двух противоположных сторонах и произвольных - на других / С.А. Халилов, В.Б. Минтюк, Д.А. Ткаченко // Авиационно-космическая техника и технология. - 2013. - № 5. - С. 40-49.

21 Халилов С.А. Собственный спектр бигармонического оператора в прямоугольнике при главных краевых условиях / С.А. Халилов, В.Б. Минтюк, Д.А. Ткаченко, В.В. Копычко // Авиационнокосмическая техника и технология. - 2014. - № 5. - С. 70-78.

22 Халилов С.А. Функция Грина основной краевой задачи для бигармонического оператора в прямоугольнике / С.А. Халилов, В.Б. Минтюк, Д.А. Ткаченко // Авиационно-космическая техника и технология. - 2015. - № 6. - С. 12-22.

23 Минтюк В.Б. Ортонормированный базис для одномерных краевых задач / В.Б. Минтюк // Авиационно-космическая техника и технология. - 2007. - № 5. - С. 32-36. 
24 Ткаченко Д.А. Ортонормированный в энергетическом пространстве бигармонического оператора базис в прямоугольнике при однородных главных краевых условиях по границе / Д.А. Ткаченко // Авиационно-космическая техника и технология. - 2014. - № 3. - С. 41-51.

25 Karchevsky A.L. Determination of the Possibility of Rock Burst in a Coal Seam / A.L. Karchevsky // Journal of Applied and Industrial Mathematics. - 2017 - Vol. 11. - No. 4. - P. 527-534. - DOI: $10.1134 /$ S1990478917040019.

26 Karchevsky A.L. Stress state estimation in coal bed under random conditions in contact zone with enclosing rocks based on inverse problem solution / A.L. Karchevsky, L.A. Nazarova, V.N. Zakharov, L.A. Nazarov // Gornyi zhurnal. - 2017. - No. 11. - P. 37-40. - DOI: 10.17580/gzh.2017.11

27 Новацкий В. Теория упругости / В.Новацкий. - М: Мир, 1975. - 872 с.

28 Karchevsky A.L. Calculation of Stresses in a Coal Seam in Presence of Gas Diffusion / A.L. Karchevsky // Journal of Applied and Industrial Mathematics. - 2016. - Vol. 10. - No. 4. - P. 482-493. - DOI: $10.1134 /$ S1990478916040049.

М.К. Кудайбергенов, А.Л. Карчевский, К.Т. Искаков

\title{
Көлденең жатқан көмір қабатының шектік ұзындығындағы кернеулі-деформацияланған күйі
}

\begin{abstract}
Мақалада жоғары жатқан жыныстардың әсерінде тұрған және екі штрек арасында жатқан шектік ұзындығы бар көмір қабаттарындағы кернеулерді есептеуге арналған аналитикалық өрнектер алынған. Бұл шешімдер алгебралық теңдеулердің шексіз жүйелерін шешуді талап етпейтін полином қосындылары мен жинақты қатар түрінде көрсетілген. Осы әдіс тәжірибедегі жеткілікті дәлдікпен, санды түрде тез арада қажетті шамаларды табуға ықпалын тигізеді. Комбайндық тәсілмен көмір қазу кезінде геомеханикалық мониторинг деректерін интерпретациялауда және мүмкін болатын тау соққысын болжау үшін өңделіп жатқан көмір қабатындағы кернеулерге мониторинг жүргізуде бұл шешімді қолдануымызға болады. Тау-кен жұмыстарын жүргізу кезінде қауіпсіздікті қамтамасыз ету үшін осы күндегі өзекті мәселелердін бірі болып табылады.
\end{abstract}

Kiлm сөздер: серпімділік теориясының жазықтық есебі, бигармоникалық теңдеулер, кернеу, көмір қабаты.

\author{
М.К. Кудайбергенов, А.Л. Карчевский, К.Т. Искаков
}

\section{Напряженно-деформированное состояние горизонтального угольного пласта конечной длины}

В статье получены аналитические выражения для вычисления напряжений в угольном пласте конечной длины, который находится под действием лежащих выше пород и между двумя штреками. Решение представлено в виде суммы полинома и сходящегося ряда. Для определения коэффициентов ряда не требуется решать бесконечных систем алгебраических уравнений. Это способствует быстрому численному нахождению требуемых величин с достаточной для практики точностью. Данное решение может быть использовано для интерпретации данных геомеханического мониторинга при комбайновой выемке угля в режиме реального времени и напряжений в разрабатываемом угольном пласте с целью прогнозирования возможности горного выброса, что до сих пор является весьма актуальной задачей обеспечения безопасности горных работ.

Ключевые слова: плоская задача теории упругости, бигармоническое уравнение, напряжение, угольный пласт. 


\section{References}

1 Puchkov L.A., Slastunov S.V., \& Kolikov K.S. (2002). Izvlechenie metana iz uholnykh plastov /The extraction of methane from coal seams]. Moscow: Izdatelstvo Moskovskoho hosudarstvennoho hornoho universiteta [in Russian].

2 Zakharov, V.I. (2002). Seismoakusticheskoe prohnozirovanie i kontrol sostoianiia i svoistv hornykh porod pri razrabotke uholnykh mestorozhdenii [Seismoacoustic prediction and control of the state and properties of rocks in the development of coal deposits]. Moscow: IHD imeni A.A. Skochinskoho [in Russian].

3 Zhenbi, L., \& Baiting, Zh. (2012). Microseism Monitoring System for Coal and Gas Outburst. International Journal of Computer Science Issues, Vol. 9, 5, 1, 24-28.

4 Zhurkov, S.N. (1985). K voprosu o fizicheskoi osnove prochnosti [To the question of the physical basis of strength]. Fizika tverdoho tela - Solid State Physics, Vol. 22, 11, 3344-3349 [in Russian].

5 Li, T.B., \& Xiao, X.P. (2008). Comprehensive integrated methods of rockburst prediction in underground engineering. Advance in Earth Science, Vol. 23, 5, 533-540.

6 Nazarov, L.A., Nazarova, L.A., Yaroslavtcev, A.F., Miroshnichenko, I.A., \& Vassiliyeva, E.V. (2011). Evoliutsiia heomekhanicheskikh polei i tekhnohennaia seismichnost pri otrabotke mestorozhdenii poleznykh iskopaemykh [Evolution of geomechanical fields and technogenic seismicity in the mining of mineral deposits]. Fiziko-tekhnicheskie problemy razrabotki poleznykh iskopaemykh - Physical and technical problems of mining, 6, 6-13 [in Russian].

7 Amussin, B.Z., \& Fadeyev, A.B. (1975). Metod konechnykh elementov pri reshenii zadach hornoi heomekhaniki [The finite element method for solving the problems of mining geomechanics]. Moscow: Nedra [in Russian].

8 Zienkiewicz, O.C., \& Taylor, R.L. (2005). The Finite Element Method for Solid and Structural Mechanics. Elsevier.

9 Dyadkov, P.G., Nazarov, L.A., \& Nazarova, L.A. (1997). Chislennoe modelirovanie napriazhennoho sostoianiia zemnoi kory i uslovii vozniknoveniia dinamicheskoi neustoichivosti seismoaktivnykh razlomov pri riftoheneze [Numerical simulation of dynamic instability of seismically active faults in rifting]. Heolohiia $i$ heofizika - Geology and Geophysics, Vol. 38, 12, 2001-2010 [in Russian].

10 Nazarov, L.A., Nazarova, L.A., \& Protassov, M.I. (2016). Rekonstruktsiia obeemnykh polei napriazhenii v uhleporodnom massive na osnove resheniia obratnoi zadachi po tomohraficheskim dannym [Reconstruction of volumetric stress fields in the coal-rock massif based on the solution of the inverse problem on tomographic data]. Fiziko-tekhnicheskie problemy razrabotki poleznykh iskopaemykh - Physical and technical problems of mining, 4, 12-21 [in Russian].

11 Aleksandrov, A.V., \& Potapov, V.D. (1990). Osnovy teorii upruhosti i plastichnosti [Fundamentals of the theory of elasticity and plasticity]. Moscow: Vysshaia shkola [in Russian].

12 Bezukhov, N.I. (1968). Osnovy teorii upruhosti, plastichnosti i polzuchesti [Fundamentals of the theory of elasticity, plasticity and creep]. Moscow: Vysshaia shkola [in Russian].

13 Kisselyov, V.A. (1976). Ploskaia zadacha teorii upruhosti [The plane problem of the theory of elasticity]. Moscow: Vysshaia shkola [in Russian].

14 Samul, V.I. (1982). Osnovy teorii upruhosti i plastichnosti [Fundamentals of the theory of elasticity and plasticity]. Moscow: Vysshaia shkola [in Russian].

15 Khalilov, S.A., Mentyuk, V.B., \& Tkachenko, D.A. (2011). Postroenie i issledovanie analitiko-chislennoho resheniia zadachi ob izhibe zhestko zashchemlennoi priamouholnoi plastiny [Construction and investigation of an analytic-numerical solution of the problem of the bending of a rigidly clamped rectangular plate]. Otkrytye informatsionnye i kompiuternye intehrirovannye tekhnolohii - Open information and computer integrated technologies, 49, 81-94 [in Russian].

16 Khalilov, S.A. (1977). Ob odnoi sisteme koordinatnykh funktsii dlia resheniia kraevykh zadach teorii plastin i obolochek [On a system of coordinate functions for solving boundary value problems in the theory of plates and shells]. Prochnost konstruktsii letatelnykh apparatov - Strength of aircraft structures, Issue 4, 60-65. Kharkov: Kharkovskii aviatsionnyi institut [in Russian].

17 Khalilov, S.A. (1978). Novye sistemy ortonormirovannykh mnohochlenov, nekotorye ikh svoistva i prilozheniia [New systems of orthonormal polynomials, some of their properties and applications]. Prochnost 
konstruktsii letatelnykh apparatov - The strength of aircraft structures, Issue 5, 46-56. Kharkov: Kharkovskii aviatsionnyi institut [in Russian].

18 Khalilov, S.A. (1984). Vychislenie nekotorykh opredelennykh intehralov, soderzhashchikh prisoedinennye funktsii Lezhandra vtoroho i chetvertoho poriadkov [Calculation of certain definite integrals containing Legendre adjoint functions of the second and fourth orders]. Strength of aircraft structures - Prochnosti konstruktsii letatelnykh apparatov, Issue 7, 158-165. Kharkov: Kharkovskii aviatsionnyi institut [in Russian].

19 Khalilov, S.A., Mentyuk, V.B., \& Tkachenko, D.A. (2013). Postroenie i issledovanie priblizhennoho analiticheskoho resheniia biharmonicheskoi problemy v priamouholnike pri odnorodnykh hlavnykh kraevykh usloviiakh [Construction and investigation of an approximate analytical solution of the biharmonic problem in a rectangle under homogeneous principal boundary conditions]. Aviatsionno-kocmicheskaia Tekhnika i Tekhnolohiia - Aerospace machinery and technology, 2, 40-49 [in Russian].

20 Khalilov, S.A., Mentyuk, V.B., \& Tkachenko, D.A. (2013). Sobstvennyi spektr biharmonicheskoho operatora $\mathrm{v}$ priamouholnike pri hlavnykh kraevykh usloviiakh [An approximate analytic solution of the biharmonic problem in a rectangle under homogeneous principal boundary conditions on two opposite sides and arbitrary ones on others]. Aviatsionno-kosmicheskaia tekhnika i tekhnolohiia - Aerospace engineering and technology, 5, 40-49 [in Russian].

21 Khalilov, S.A., Mentyuk, V.B., Tkachenko, D.A., \& Kopychko, V.V. (2014). Sobstvennyi spektr biharmonicheskoho operatora $\mathrm{v}$ priamouholnike pri hlavnykh kraevykh usloviiakh [The proper spectrum of a biharmonic operator in a rectangle under the main boundary conditions]. Aviatsionno-kosmicheskaia tekhnika i tekhnolohiia - Aerospace Engineering and Technology, 5, 70-78 [in Russian].

22 Khalilov, S.A., Mentyuk, V.B., \& Tkachenko, D.A. (2015). Funktsiia Hrina osnovnoi kraevoi zadachi dlia biharmonicheskoho operatora $\mathrm{v}$ priamouholnike [Green's function of the basic boundary-value problem for a biharmonic operator in a rectangle]. Aviatsionno-kosmicheskaia tekhnika i tekhnologiia - Aerospace Engineering and Technology, 6, 12-22 [in Russian].

23 Mentyuk, V.B. (2007). Ortonormirovannyi bazis dlia odnomernykh kraevykh zadach [Orthonormal basis for one-dimensional boundary value problems]. Aviatsionno-kosmicheskaia tekhnika i tekhnolohiia - Aerospace Engineering and Technology, 5, 32-36 [in Russian].

24 Tkachenko, D.A. (2014). Ortonormirovannyi v enerheticheskom prostranstve biharmonicheskoho operatora bazis $\mathrm{v}$ priamouholnike pri odnorodnykh hlavnykh kraevykh usloviiakh po hranitse [An orthonormal basis in the energy space of a biharmonic operator is a rectangle under homogeneous principal boundary conditions along the boundary]. Aviatsionno-kosmicheskaia tekhnika i tekhnolohiia - Aerospace Engineering and Technology, 3, 41-51 [in Russian].

25 Karchevsky, A.L. (2017). Determination of the Possibility of Rock Burst in a Coal Seam. Journal of Applied and Industrial Mathematics, Vol. 11, 4, 527-534. DOI: 10.1134/S1990478917040019.

26 Karchevsky, A.L., Nazarova, L.A., Zakharov, V.N., \& Nazarov, L.A. (2017). Stress state estimation in coal bed under random conditions in contact zone with enclosing rocks based on inverse problem solution. Gornyi zhurnal - Mining Journal, 11, 37-40. DOI: 10.17580/gzh.2017.11

27 Novatckiy, V. (1975). Teoriia upruhosti [Theory of elasticity]. Moscow: Mir [in Russian].

28 Karchevsky, A.L. (2016). Calculation of Stresses in a Coal Seam in Presence of Gas Diffusion. Journal of Applied and Industrial Mathematics, Vol. 10, 4, 482-493. DOI: 10.1134/S1990478916040049. 